\title{
G-Protein Coupled Receptor 39
}

National Cancer Institute

\section{Source}

National Cancer Institute. G-Protein Coupled Receptor 39. NCI Thesaurus. Code C29641.

G-protein coupled receptor 39 ( $453 \mathrm{aa}, \sim 51 \mathrm{kDa}$ ) is encoded by the human GPR39 gene.

This protein is involved in the activation of second messenger signaling. 